\title{
Analisis Optimalisasi Teknologi Digital di Era Revolusi Industri 4.0 dalam Mengembangkan Kawasan Industri Pariwisata Halal guna Meningkatkan Perekonomian Lokal Kecamatan Gunungpati Kota Semarang
}

\author{
Moch Faizal Rachmadi \\ Universitas Negeri Semarang \\ Email : faizal.rachmadi@students.unnes.ac.id
}

\begin{abstract}
The use of appropriate digital technology can be an opportunity for Indonesia to develop its tourism sector to become a halal tourism industry to improve the national economy. Gunungpati District is one of the regions that has superior potential in the field of tourism. However, the absence of a halal tourism industry area and the use of technology that is not maximized make the tourism sector not too attractive to the wider community. Therefore, efforts are needed to optimize the flow of this digital technology massively. The purpose of this study is to improve the use of digital technology in realizing Gunungpati District into a halal tourism area. The method used in this study is descriptive qualitative analysis method with secondary data to describe the phenomena that occur in the field in explaining the data to support this work. Based on the study conducted it can be concluded that the use of appropriate technology can improve local and national economies through halal tourism industry.
\end{abstract}

\section{Keywords: the halal tourism industry, local economy, industrial revolution 4.0, digital technology.}

\begin{abstract}
Abstrak
Pemanfaatan teknologi digital yang tepat guna dapat menjadi peluang Indonesia dalam mengembangkan sektor pariwisatanya menjadi kawasan industri wisata halal untuk meningkatkan perekonomian nasional. Kecamatan Gunungpati merupakan salah satu wilayah yang mempunyai potensi unggul dibidang pariwisata. Akan tetapi belum adanya kawasan industri pariwisata halal dan pemanfaatan teknologi yang kurang maksimal membuat sektor pariwisata ini belum terlalu diminati masyarakat luas. Oleh karena itu, diperlukan upaya dalam mengoptimalkan arus teknologi digital ini. Tujuan dari penelitian ini adalah untuk meningkatkan pemanfaatan teknologi digital dalam mewujudkan Kecamatan Gunungpati menjadi kawasan wisata halal. Metode yang digunakan dalam penelitian ini adalah metode analisis kualitatif deskriptif dengan data sekunder untuk menggambarkan fenomena-fenomena yang terjadi di lapangan dalam menjelaskan data-data untuk menunjang karya ini. Berdasarkan studi yang dilakukan dapat disimpulkan bahwa pemanfaatan teknologi yang tepat dapat meningkatkan perekonomian lokal maupun nasional melalui kawasan industri pariwisata halal.
\end{abstract}

Kata Kunci: industri pariwisata halal, perekonomian lokal, revolusi industri 4.0, teknologi digital. $i$

\section{Pendahuluan}

Secara singkat, pengertian industri 4.0 adalah tren di dunia industri yang menggabungkan teknologi otomatisasi dengan teknologi cyber. Pada industri 4.0, teknologi manufaktur sudah masuk pada tren otomatisasi dan pertukaran data. Hal tersebut mencakup sistem cyber- 
fisik, internet of things (IoT), komputasi awan, dan komputasi kognitif. Revolusi industri 4.0 akan membawa banyak perubahan dengan segala konsekuensinya, industri akan semakin kompak dan efisien. Namun ada pula risiko yang mungkin muncul, misalnya berkurangnya sumber daya manusia karena digantikan oleh mesin atau robot. Dunia saat ini memang tengah mencermati revolusi industri 4.0 ini secara saksama. Berjuta peluang ada di situ, tapi di sisi lain terdapat berjuta tantangan yang harus dihadapi. ${ }^{1}$

Menurut Airlangga Hartanto revolusi industri 4.0 memberi kesempatan bagi Indonesia untuk berinovasi. Revolusi yang fokus pada pengembangan ekonomi digital dinilai menguntungkan bagi Indonesia. ${ }^{2}$ Diera revolusi industri 4.0 ini sangat erat kaitannya dengan pemanfaatan teknologi digital secara maksimal. Pengguna internet didunia pada akhir januari 2018 mencapai 4 miliar. Ini artinya, lebih dari setengah populasi didunia terkoneksi dengan internet. Secara global, pengguna media sosial tumbuh sebesar 13 persen dalam waktu 12 bulan terakhir. Asia Tengah dan Selatan mencatat kenaikan tercepat yakni masing-masing 90 persen dan 33 persen. Arab Saudi memperlihatkan peningkatan terbesar dibandingkan negara-negara lain yakni 32 persen. Disusul India sebesar 31 persen dan Indonesia 23 persen. ${ }^{3}$ Pengguna internet di Indonesia memang cukup besar dan potensial.

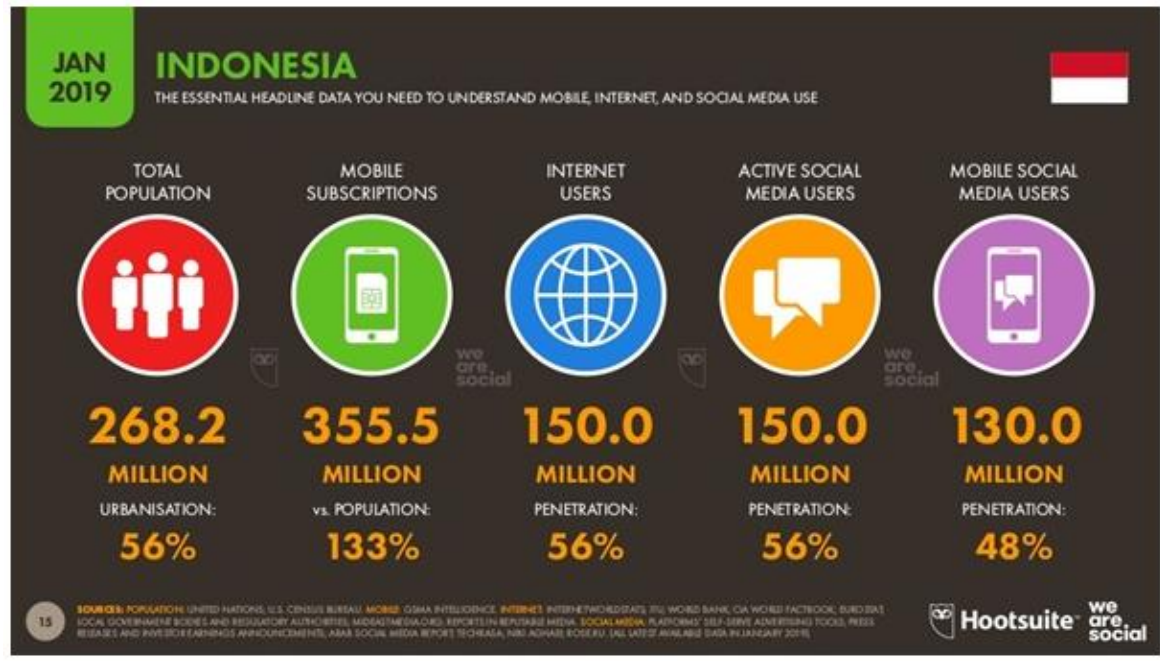

Sumber: Hootsuite Inc dan We Are Social

Gambar 1. The Global State of Digital in 2019

Jumlah pengguna internet di Indonesia bertambah 17 juta selama setahun hingga Januari 2019, atau naik 13\% dibandingkan dengan periode 2018, berdasarkan data yang dirilis oleh Hootsuite Inc. Alhasil, total pengguna internet di Tanah Air saat ini mencapai 130 juta, atau 56\% dari total populasi yang mencapai 268,2 juta. Laporan berjudul The Global State of Digital in 2019 Report itu menyebut bahwa pengguna media sosial aktif di Indonesia tahun ini juga bertambah 20

\footnotetext{
${ }^{1}$ Tresya, Viranda "Revolusi Industri 4.0: Pengertian, Prinsip dan Tantangan Generasi Milenial", diakses dari https://www.maxmanroe.com/revolusi-industri-4-0.html pada tanggal 08 April 2019 pukul 06.00.

${ }^{2}$ Kementerian Perindustrian RI. 2016. "Making Indonesia 4.0: Strategi RIMasuk Revolusi Industri Ke-4", diakses dari http://www.kemenperin.go.id/artikel/18967/Making-Indonesia-4.0:-Strategi-RI-Masuki-Revolusi-Industri-Ke-4 pada tanggal 08 April 2019 pukul 07.01

3 Jamaludin, Fauzan "Media Sosial Merajai Pengguna Internet Didunia", diakses dari https://www.merdeka.com/teknologi/media-sosial-merajai-pengguna-internet-di-dunia.html pada tanggal 21 Mei 2019 pukul 12.04
} 
juta (13\%) menjadi 150 juta, atau sama dengan jumlah pengguna internet. Sementara itu, mereka yang menggunakan media sosial lewat perangkat mobile mencapai 130 juta atau naik 10 juta (8,3\%) selama setahun terakhir. ${ }^{4}$ Internet dapat menjadi peluang yang positif dalam mengembangkan perekonomian apabila dimanfaatkan secara tepat.

Salah satu hal yang dapat dilakukan dalam upaya optimalisasi teknologi digital diera revolusi industri 4.0 ini adalah pengembangan wisata halal. Wisata halal sudah menjadi gaya hidup masyarakat didunia dan mempunyai potensi yang sangat menjanjikan. Tidak hanya orang muslim saja yang dapat menikmati akses pariwisata halal, orang didunia yang non muslim pun sudah menjadikan halal sebagai life style.

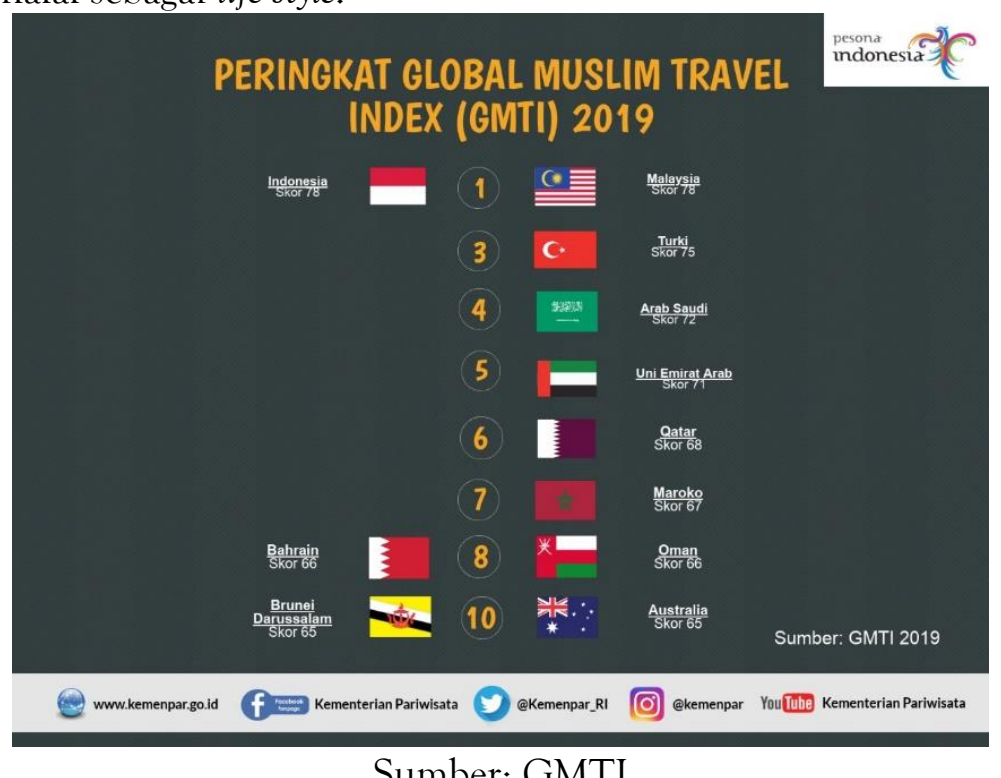

Gambar 2. Peringkat Global Muslim Travel Index (GMTI) Tahun 2019

Pada 2019, Indonesia menjadi Destinasi Terbaik Wisata Halal Dunia bersama Malaysia. Indonesia berhasil naik satu peringkat dibandingkan tahun 2018. Berdasarkan Global Muslim Travel Index (GMTI), kedua negara ini berada di peringkat pertama dengan skor 78. Peringkat ketiga dan keempat diisi oleh Turki (75) dan Arab Saudi (72) dengan sama-sama naik satu peringkat dari tahun sebelumnya. Posisi ke-5 ditempati Uni Emirat Arab yang harus rela turun 3 peringkat dengan poin $71 .^{5}$

Adanya peluang seperti perkembangan arus teknologi digital yang semakin masif dan prospek kunjungan wisata halal dunia yang semakin meningkat seharusnya Indonesia sigap dalam mensiasatinya. Hal yang dilakukan pemerintah salah satunya adalah memberikan perhatian khusus kepada sektor pariwisata. Sektor pariwisata saat ini menjadi salah satu sektor unggulan bagi pemerintah Republik Indonesia dalam mendapatkan devisa negara. Perkembangan pariwisata dewasa ini sangat pesat dan memberikan peluang terhadap pertumbuhan ekonomi nasional

4 Basari, MT "Setahun, Jumlah Pengguna Internet Indonesia Bertambah 17 Juta", diakses dari https://teknologi.bisnis.com/read/20190228/101/894799/setahun-jumlah-pengguna-internet-indonesiabertambah-17-juta pada tanggal 21 mei 2019 pukul 13.12.

5 Jayani, DH "Bersama Malaysia, Indonesia Jadi Destinasi Wisata Halal Terbaik di Dunia", diakses dari https://databoks.katadata.co.id/datapublish/2019/04/09/bersama-malaysia-indonesia-jadi-destinasi-wisata-halalterbaik-di-dunia pada tanggal 22 Mei 2019 pukul 05.45. 
maupun regional. Indonesia bisa saja menjadi tuan rumah dalam penyediaan obyek wisata halal terbesar dan utama didunia mengingat mayoritas penduduknya beragama muslim. Selain itu, prospek kunjungan wisata halal ke Indonesia pun terus mengalami peningkatan setiap tahunnya.

Catatan Badan Pusat Statistik (BPS), dalam tiga tahun terakhir sektor pariwisata menjadi penyumbang devisa terbesar kedua setelah industri sawit mentah. Pada 2017, sektor pariwisata menyumbang devisa tidak kurang dari US\$16, 8 miliar. Setahun kemudian, jumlahnya naik menjadi US\$20 miliar. Ambisi pemerintah menggenjot sektor pariwisata halal tentu wajar mengingat sektor tersebut mengalami tren pertumbuhan signifikan belakangan ini. Data Kementerian Pariwisata (Kemenpar) menyebut, jumlah wisatawan muslim-asing pada 2017 mencapai 2, 5 juta orang. Di 2018, jumlah itu naik signifikan menjadi 3,5 juta orang. Jika tren itu terus bertahan, target kunjungan 5 juta wisatawan muslim-asing tentu bukan hal yang sulit dicapai.Pertumbuhan wisata halal ini merupakan imbas dari tren perjalanan muslim global yang dalam waktu tiga tahun ini mengalami peningkatan. Data Cresent Rating menyebutkan, pada 2016 jumlah perjalanan muslim mencapai 121 juta. Sementara itu pada 2017, jumlah perjalanan muslim global mencapai 131 juta. Cresent Rating memproyeksikan perjalanan muslim global pada 2020 mencapai 156 juta atau mencapai 10\% dari total perjalanan global. ${ }^{6}$ Akan tetapi prospek junjungan wisata halal Indonesia masih rendah jika dibandingkan dengan negara tetangga seperti Malaysia, Singapura dan Thailand. Menurut Arief Yahya selaku Menteri Pariwisata Indonesia hal ini disebabkan beberapa hal, diantaranya adalah kurang banyaknya destinasi wisata halal di Indonesia, belum adanya sinergitas yang kuat antar pihak dalam mengembangkan wisata halal di Indonesia, belum adanya promosi yang masif dan juga pelayanan terhadap wisatawan yang kurang optimal. $^{7}$

Upaya yang dilakukan pemerintah pusat adalah terus menggenjot potensi wisata daerah salah satunya di Provinsi Jawa Tengah. Provinsi Jawa Tengah berencana akan mengembangkan 67 desa potensial untuk dijadikan desa wisata dan program ini mendapat alokasi dana dari Kementerian Pariwisata dan Ekonomi Kreatif sebesar Rp. 5,3 Miliar. ${ }^{8}$ Salah satu sasaran dari Pemerintah Provinsi Jawa Tengah ini sendiri adalah Kecamatan Gunungpati Kota Semarang. Diwilayah ini memiliki banyak sekali potensi pariwisata unggul seperti desa wisata kandri dan sebagainya. Desa wisata ini juga tersedia beberapa obyek yang dapat dikunjungi seperti goa kreo, waduk jatibarang dan masih banyak lagi. Akan tetapi pariwisata ini mempunyai beberapa kendala utama. Menurut Sudanti Budiardjo, anggota Dewan Pertimbangan Pembangunan Kota (DP2K) Kota Semarang, wisata di Kecamatan Gunungpati ini masih ada yang perlu diperbaiki dan dikembangkan lagi. Hal itu seperti perbaikan infrastruktur, fasilitas wisata, pemanfaatan teknologi bahkan promosi kepada masyarakat yang belum optimal. ${ }^{9}$

\footnotetext{
6 Hidayah, SN “Prospek Wlsata Halal Indonesia di Kancah Global”, diakses dari https://www.alinea.id/kolom/prospek-wisata-halal-indonesia-di-kancah-global-b1Xgf9jV6 pada tanggal 22 Mei 2019 pukul 05.12.

7 H, Yanuar "Prospek baik Wisata Halal Indonesia", diakses dari https://www.liputan6.com/lifestyle/read/3375370/prospek-baik-wisata-halal-indonesia pada tanggal 22 Mei 2019 pukul 02.24.

8 Tofan, Muhammad dkk, "Strategi Pengembangan Obyek Desa Wisata Kandri Kecamatan Gunungpati Kota Semarang ", Islamic Banking and Finance Review, Vol. 3 No. 1, 2016, HIm. 29-49.

9 Semarang "Petro "Potensi Wisata Gunungpati Menjanjikan", diakses dari https://www.suaramerdeka.com/smcetak/baca/148375/potensi-wisata-gunungpati-menjanjikan pada tanggal 22 Mei 2019 pukul 14.49 .
} 
Oleh karena itu, diperlukan tindakan cepat dalam mengatasi permasalahan tersebut salah satunya melalui pemanfaatan dan optimalisasi teknologi secara maksimal. Optimalisasi teknologi digital yang terintegrasi pastinya mampu menciptakan pariwisata di Kecamatan Gunungpati Kota Semarang menjadi lebih baik lagi dengan megembangkannya menjadi kawasan industri pariwisata halal, yang penikmatnya tidak hanya masyarakat muslim melainkan untuk semua kalangan. Hal ini diperlukan karena pariwisata halal mempunyai peluang yang sangat menjanjikan. Adanya optimalisasi teknologi digital ini informasi akan lebih cepat sampai kepada konsumen selain itu juga lebih efektif dan efisien karena semuanya berbasis online system. Konsep pariwisata halal ini merupakan serangkaian proses meliputi perizinan, pelaksanaan, pencarian informasi, media promosi transaksi dan segala macam aktivitas disesuaikan dengan kaidah serta aturan islam yang terintegrasi sistem.

\section{Metode Penelitian}

Penelitian ini merupakan penelitian kualitatif. Metode penelitian yang digunakan dalam penelitian ini adalah telaah literatur (literature review) dari berbagai penelitian yang telah dilakukan sebelumnya. Metode pengumpulan data yang digunakan yaitu data sekunder yang diperoleh dari jurnal, buku dokumentasi, dan internet. Diantaranya yaitu data-data yang dipublikasikan oleh lembaga-lembaga yang memiliki kredibilitas terpercaya, seperti data dari Kementerian Pariwisata dan Ekonomi Kreatif, Kementerian Perindustrian dan masih banyak lagi.

Metode Analisis data dalam penelitian ini dilakukan dengan metode analisis deskriptif. Data-data yang sudah diperoleh kemudian dianalisis dengan metode analisis deskriptif. Metode analisis deskriptif dilakukan dengan menyusun data yang diperoleh kemudian diinterpretasikan dan dianalisis sehingga memberikan informasi bagi pemecahan masalah yang dihadapi.

\section{Hasil Dan Pembahasan \\ Pemanfaatan Teknologi Digital yang Tepat Guna}

Media mempunyai peranan krusial dalam pertumbuhan dan kemajuan pariwisata, salah satunya dengan menyampaikan informasi secara mendalam tentang objek-objek wisata yang dibutuhkan oleh turis domestik maupun mancanegara. Di era kemajuan teknologi, ada perubahan perilaku para turis di mana mereka menginginkan lebih banyak informasi mengenai objek wisata. ${ }^{10}$ Kehadiran teknologi berperan penting dalam mempermudah kehidupan masyarakat Indonesia dalam berbagai hal, salah satunya sektor pariwisata. Perubahan perilaku wisatawan terlihat ketika search and share $70 \%$ sudah melalui perangkat digital. Teknologi merupakan salah satu variabel penguatan manajemen strategi pariwisata seperti tertuang dalam analisis PESTEL (Politic, Economy, Social, Technology, Environment, dan Legal). ${ }^{11}$

\footnotetext{
10 Ant "Memanfaatkan Media Digital untuk Kemajuan Pariwisata", diakses dari https://www.wartaekonomi.co.id/read177260/memanfaatkan-media-digital-untuk-kemajuan-pariwisata.html pada tanggal 21 Mei 2019 pukul. 13.24.

11 Rizkiniswara, Leski “Pentingnya Teknologi dalam Sektor Pariwisata" diakses dari https://aptika.kominfo.go.id/2019/04/pentingnya-teknologi-dalam-sektor-pariwisata/ pada tanggal 21 mei 209 pukul 15.42 .
} 


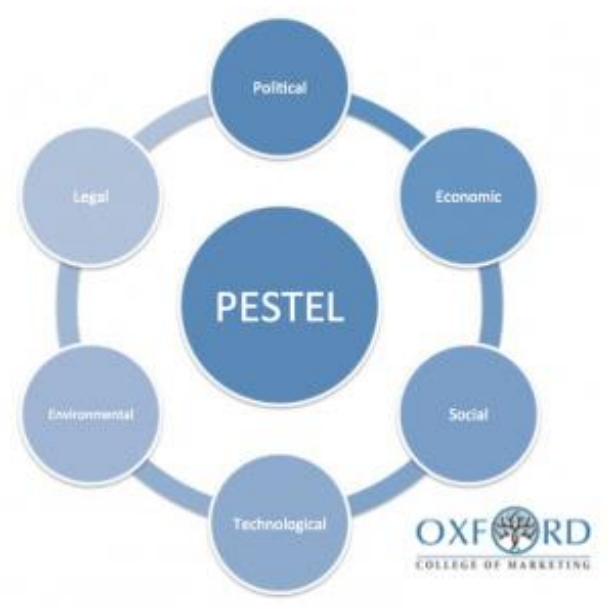

Sumber: DITJEN APTIKA KOMINFO

Gambar 3. Analisis PESTEL

Tahapan penggunaan teknologi dalam melakukan perjalanan wisata antara lain perencanaan (planning): Online Reservations. Hadirnya aplikasi-aplikasi penunjang online reservation memberikan kemudahan dalam pemesanan sehingga sangat diminati oleh masyarakat di era digital ini. Kemudian dalam perjalanan (On The Road): Mobile Phone $\rightarrow$ The best Co-pilot. Hadirnya smartphone menjadi pemandu terbaik dalam melakukan perjalanan wisata. Saat seseorang berwisata ia bisa mendapatkan berbagai informasi hanya dengan smartphone yang dimilikinya. Mulai dari tempat wisata yang ingin dikunjungi, cara menuju ke tempat tersebut, tempat makan khas suatu daerah, hingga tempat belanja oleh-oleh dapat diketahui dengan smarphone yang kita miliki. Kemudian yang terakhir adalah setelah serjalanan (Post-Trip): Sharing is Living. Maraknya media sosial saat ini merubah pola hidup masyarakat, saat ini share atau posting kegiatan kita menjadi kebiasan sehari-hari masyarakat Indonesia, tidak terkecuali saat kita sedang melakukan perjalanan wisata. Dari tiga hal diatas dapat kita simpulkan bahwa hadirnya teknologi sangat penting dan tidak dapat ditolak dalam mengembangkan sektor pariwisata. Menteri Pariwisata Arief Yahya selalu mengatakan, "Saat ini industri dunia telah bergeser ke arah industri digital era 4.0, sehingga teknologi digital menjadi sebuah keniscayaan". ${ }^{12}$

Berdasarkan Global Muslim Travel Index (GMTI) yang menjadi acuan standar wisata halal di dunia, bisa dirincikan menjadi 3 kelompok yaitu destinasi ramah keluarga, layanan dan fasilitas di destinasi yang ramah muslim dan kesadaran halal dan pemasaran estinasi. Dalam kelompok ini juga dijabarkan lagi menjadi 11 indikator diantaranya adalah terkait dengan komunikasi dan penggunaan teknologi digital. ${ }^{13}$ Optimalisasi teknologi ini sangat berpengaruh dan berperan penting dalam segala arus komunikasi, termasuk dalam hal penyediaan informasi, online licensing process dan masih banyak lagi.

\section{Pariwisata dalam Perspektif Al-Qur'an dan Hadits}

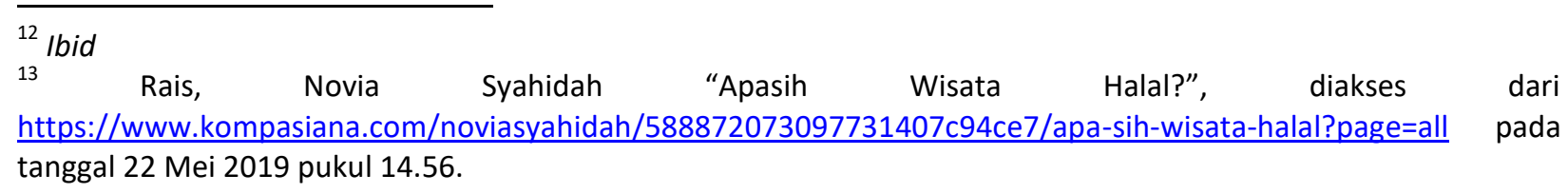


Pariwisata Islam meliputi aktivitas yang dilaksanakan oleh umat muslim di destinasi tempat wisata yang menerapkan prinsip-prinsip islam untuk tujuan relaksasi maupun hiburan. Prinsipprinsip tersebut meliputi pemberlakuan konsep halal dalam setiap perjalanan wisata yang dilakukan atau dikenal dengan istilah halal tourism. ${ }^{14}$ Konsep Halal (bahasa Arab), berarti diperkenankan/diperbolehkan. Konsep ini tidak hanya diterapkan untuk makanan, namun juga termasuk kosmetik, vaksin, dan pariwisata. ${ }^{15} \mathrm{Hal}$ ini juga termasuk menyediakan paket wisata dan destinasi yang menyediakan kebutuhan umat muslim saat menjalankan kegiatan wisata.

\section{Konsep Wisata Halal}

Industri halal mengalami perkembangan yang pesat dalam beberapa tahun ini. Gaya hidup halal yang identik dengan umat Muslim tersebar hingga ke berbagai negara, bahkan ke negaranegara dengan penduduk muslim minoritas maupun non muslim. Halal menjadi indikator universal untuk jaminan kualitas produk dan standar hidup ${ }^{16}$. Halal biasanya hanya dikaitkan dengan hal-hal terkait kebendaan saja. Namun demikian, dalam Islam halal mencakup perbuatan dan pekerjaan atau biasa disebut dengan Muamalah. Halal dapat didefinisikan sebagai standar kualitas yang sesuai dengan hukum Shariah Islamiah dan digunakan pada setiap aktivitas yang dilakukan oleh umat Muslim.

Berikut adalah definisi dari wisata halal menurut beberapa ahli, antara lain sebagai berikut:

Tabel 1. Definisi Wisata Halal

\begin{tabular}{ll}
\hline \multicolumn{1}{c}{ Penulis } & \multicolumn{1}{c}{ Definis } \\
\hline Battour dan Ismail (2016) & $\begin{array}{l}\text { Kegiatan dalam pariwisata yang 'diizinkan atau } \\
\text { dibolehkan' menurut ajaran Islam. }\end{array}$ \\
Mohsin et al. (2016) & $\begin{array}{l}\text { Penyediaan produk dan layanan pariwisata yang } \\
\text { memenuhi kebutuhan wisatawan muslim seusai } \\
\text { ajaran agama Islam. }\end{array}$ \\
Halbase (2015) & $\begin{array}{l}\text { Menawarkan paket wisata dan tujuan yang khusus } \\
\text { untuk memenuhi pertimbangan dan kebutuhan } \\
\text { muslim. }\end{array}$ \\
\hline
\end{tabular}

Sumber: Satriana ED dan Hayyun DF

Wisata halal muncul dari kebutuhan wisatawan muslim sesuai ajaran Islam yakni berlandaskan Al-Quran dan Hadits. Konsep wisata halal merupakan aktualisasi dari konsep keIslaman yakni nilai halal dan haram menjadi tolak ukur utamanya. Hal ini berarti seluruh aspek kegiatan wisata tidak terlepas dari sertifikasi halal yang harus menjadi acuan bagi setiap pelaku

\footnotetext{
${ }^{14}$ Doğan, M. 2011. Türkiye' deislamiturizmingelişimi: 2002-2009. In Political Economy, Crises and Development. In, Şiriner, I.., Morady, F., Mika, J., Aydın, M., Koç, Ş. A., Kapucu, H. \&Doğan, E. (eds.), 471- 487. İstanbul: IJOPEC Publication.

${ }^{15}$ Henderson, JC. 2010. "Sharia-compliant hotel," Tourism and Hospitality Research, Vol. 10 No. 3, 2010, HIm 246254.

${ }^{16}$ Gillani, SH, ljaz F dan Khan MM, "Role of Islamic Financial Institutions in Promotion of Pakistan Halal Food Industry", Islamic Banking and Finance Review, Vol. 3 No. 1, 2016, HIm. 29-49.
} 
pariwisata. ${ }^{17}$ Hingga kini, belum ada prinsip-prinsip atau syarat utama wisata halal yang disepakati dan tidak banyak literatur atau praktisi yang mendiskusikan dan memaparkan hal tersebut. ${ }^{18}$

\section{Indikator Penilaian Pariwisata Halal}

Berdasarkan Global Muslim Travel Index (GMTI) yang menjadi acuan standar wisata halal di dunia, bisa dirincikan kurang lebih menjadi tiga kelompok kriteria wisata halal yang diulas seperti destinasi ramah keluarga, layanan dan fasilitas di destinasi yang ramah muslim dan juga kesadaran halal dan pemasaran destinasi. ${ }^{19}$

Lalu dari tiga kriteria ini, ada 11 indikator turunan yang menjadi acuannya. Untuk kriteria pertama, destinasi ramah keluarga yaitu destinasi wisata harus ramah keluarga, keamanan umum bagi wisatawan muslim dan jumlah kedatangan wisatawan muslim yang cukup ramai. Untuk kriteria kedua, layanan dan fasilitas di destinasi yang ramah muslim berupa pilihan makanan dan jaminan halalnya, akses ibadah yang mudah dan baik, fasilitas di bandara yang ramah muslim serta opsi akomodasi yang memadai. Kemudian untuk kriteria tiga, kesadaran halal dan pemasaran destinasi dikelompokkan lagi menjadi 4 yaitu kemudahan komunikasi, jangkauan dan kesadaran kebutuhan wisatawan muslim, konektivitas transportasi udara serta persyaratan visa. ${ }^{20}$

\section{Potensi Pariwisata di Kecamatan Gunungpati}

Negara-negara di dunia saat ini tengah bersaing menggenjot sektor pariwisata untuk memperoleh devisa. Khusus Indonesia, sektor pariwisata beberapa tahun belakangan memang menjadi andalan utama untuk menggerakkan pertumbuhan ekonomi. Presiden Joko Widodo bahkan telah menetapkan pariwisata sebagai leading sector dan prioritas utama dalam perekonomian. Ini beralasan karena pariwisata pada dasarnya mampu menciptakan pusat-pusat pertumbuhan ekonomi secara merata di seluruh wilayah Tanah Air, baik di bagian barat, tengah maupun timur. Pariwisata jadi primadona baru pendorong perekonomian karena pertumbuhannya mencapai 22\%. Ini empat kali lipat jika dibandingkan dengan pertumbuhan ekonomi kita yang hanya mencapai 5,3\%. Tidak sulit bagi Indonesia untuk mendatangkan devisa dari pariwisata. Apalagi, beragam destinasi unik yang keindahannya sudah dikenal dunia dimiliki oleh negara kepulauan ini. ${ }^{21}$

Kecamatan Gunungpati Kota Semarang merupakan salah satu wilayah di Jawa Tengah yang mempunyai potensi wisata yang unggul. Salah satu unggulan wisata diwilayah ini adalah Desa Wisata Kandri. Didesa ini ada beberapa obyek wisata yang dapat dikunjungi seperti gua kreo, waduk jatibarang dan masih banyak lagi. Gua kreo ini merupakan obyek wisata yang masih alami sehingga dihuni oleh puluhan monyet berekor panjang. Pengunjung juga dapat menikmati kuliner tradisional seperti getuk ketek yang terbuat dari bahan singkong, tape singkong, tape dodol, makanan dan makanan ringan yang terbuat dari tepung moca. Warga desa Kandri

\footnotetext{
${ }^{17}$ Satriana, ED dan Hayyun DF “Wisata Halal: Perkembangan, Peluang dan Tantangan", Jurnal of Halal Product and Research, Vol. 1 No. 2, 2018, HIm. 32-43.

${ }^{18}$ El-Gohary, H. 2016. Halal Tourism, is it Really Halal?. Tourism Management Perspective. 19: 124-130.

19 Rais, Novia Syahidah "Apasih Wisata Halal?", diakses dari https://www.kompasiana.com/noviasyahidah/588872073097731407c94ce7/apa-sih-wisata-halal?page=all pada tanggal 22 Mei 2019 pukul 14.56.

${ }^{20} \mathrm{lbid}$

21 Koran Sindo. 2018. "Prospek Wisata Halal Indonesia" diakses dari https://nasional.sindonews.com/read/1355812/16/prospek-wisata-halal-indonesia-1542585387 pada tanggal 09 April 2019 pukul 07.09.
} 
mempertahankan kebudayaan lokal seperti ketoprak, wayang kulit, wayang suket (rumput), dan pertunjukan lesung sebagai pertunjukan seni. ${ }^{22}$

Masih di Kecamatan Gunungpati, terdapat wisata Desa Nongkosawit yang memiliki pemandangan indah dengan lembah dan ngarai. Desa Nongkosawit memiliki potensi pertanian dan buah-buahan seperti durian, jeruk, buah naga, dan rambutan. Peternakan ayam, sapi, tikus putih dan, domba. Serta pertunjukan kesenian tarian tradisional si Golo-Golo dan Kuntulan yang dibawakan masyarakat setempat. ${ }^{23}$

\section{Pihak yang Terlibat Pengembangan Pariwisata Halal di Gunungpati}

Seluruh pihak mulai dari pemerintah pusat, pemerintah daerah, pelaku industri pariwisata, masyarakat dan swasta harus terus berupaya dalam mengembangkan sektor pariwisata khususnya di Kecamatan Gunungpati Kota Semarang. Prospek pariwisata halal tentunya lebih menjanjikan. Masyarakat tidak lagi canggung maupun khawatir terkait segala hal dan proses yang ada dalam kawasan industri pariwisata halal tersebut karena semuanya telah dijamin sesuai dengan ajaran Islam. Sinergitas antar stake holder ini diperlukan demi menunjang perkembangan pariwisata halal di Gunungpati ini. Pemerintah pusat maupun daerah sebagai pemegang kebijakan seharusnya mengeluarkan peraturan yang dapat memberikan keuntungan dan aspek positif terhadap sektor perekonomian terutama berkaitan dengan pemanfaatan teknologi digital.

Masyarakat sebagai subyek utama harus berperan aktif dalam upaya mempromosikan dan terus mengembangkan pariwisata Gunungpati menjadi kawasan pariwisata halal di Indonesia. Selain itu, pelaku industri pariwisata halal juga harus melakukan inovasi dan diversifikasi produk wisatanya tersebut, hal ini bertujuan agar wisatawan tidak gampang bosan dan semakin tertarik untuk mengunjunginya. Ada beberapa cara yang dapat dilakukan seperti optimalisasi teknologi digital dalam proses perizinan, sebagai sumber informasi bahkan media promosi agar produk wisata lebih dikenal oleh masyarakat Indonesia dan juga dunia.

\section{Upaya Pemerintah dalam Mendongkrak Sektor Pariwisata Halal}

Dalam pengembangan pariwisata halal, Kementerian Pariwisata bekerjasama dengan Dewan Syariah Nasional (DSN), Majelis Ulama Indonesia (MUI) dan Lembaga Sertifikasi Usaha (LSU). Mereka bekerja sama untuk mengembangkan potensi dan standar pariwisata yang menjunjung tinggi budaya dan nilai-nilai Islami. Standar pariwisata syariah ini nantinya akan dituangkan dalam Peraturan Menteri Pariwisata dan Ekonomi Kreatif. ${ }^{24}$ Untuk mewujudkan pengembangan wisata halal dalam industri pariwisata nasional, Dirjen Pemasaran Pariwisata akan melakukan pelatihan SDM, capacity building, dan juga sosialisasi. Kementerian Pariwisata juga akan belajar dari negara-negara lain yang sudah menerapkan konsep wisata halal, seperti Malaysia yang sudah lebih dulu dikenal sebagai destinasi wisata halal, serta melakukan sosialisasi dengan organisasi-organisasi pelaku pariwisata di Indonesia, misalnya Perhimpunan Hotel dan Restoran Indonesia (PHRI) dan Association of the Indonesia Tours and Travel (ASITA). PHRI bisa memastikan

22 Insetyonoto "WISATA SEMARANG: Yuk AKhir Pekan ke Desa Ini" diakses dari https://semarang.solopos.com/read/20160408/515/708648/wisata-semarang-yuk-akhir-pekan-ke-desa-wisata-ini pada tanggal 22 Mei 2019 pukul 06.15.

${ }^{23} \mathrm{Ibid}$

24 Fatkurrohman. 2018. "Konsep dan Ruang Lingkup Wisata Halal", diakses dari https://wisatahalal.sv.ugm.ac.id/2018/08/23/konsep-dan-ruang-lingkup-wisata-halal/ pada tanggal 10 April 2019 pukul 12.00. 
hotel-hotelnya halal untuk wisatawan Muslim, sementara ASITA bisa membuat paket-paket wisata ke tempat wisata religi dan ziarah. ${ }^{25}$

Pengembangan wisata halal itu sangat penting karena manfaatnya tidak hanya dapat dirasakan oleh wisatawan muslim melainkan bersifat terbuka untuk semua orang. Diharapkan wisata halal dapat menjadikan Indonesia sebagai destinasi yang ramah untuk wisatawan Muslim. Ciri wisata halal antara lain ada paket-paket wisata halal yang meliputi destinasi ramah wisatawan muslim, serta hotel, restoran, dan spa yang halal. Salah satu tujuan Kementerian Pariwisata dan Ekonomi Kreatif meluncurkan wisata halal adalah menarik semakin banyak wisatawan asing. Terselip pula alasan lain yang mendasari diluncurkannya wisata jenis ini. Indonesia meluncurkan wisata halal bukan semata untuk menarik wisatawan asing hingga meningkatkan jumlah kunjungannya per tahun. Keinginan dari turis domestik juga menjadi alasan karena menurut Kemenparekraf, semakin banyak wisatawan yang mengungkapkan kebutuhan mereka akan wisata halal. $^{26}$

Kementerian Pariwisata RI bekerjasama dengan Majelis Ulama Indonesia (MUI) dalam menentukan standar halal produk pariwisata. Sertifikasi halal yang dikeluarkan MUI sudah melewati penilaian dan pengecekan dari Badan Pemeriksa Obat dan Makanan (BPOM) sehingga masyarakat baik muslim maupun non muslim tidak perlu khawatir dalam mengkonsumsi produk tersebut. Kemudian upaya yang dilakukan pemerintah daerah dalam hal ini adalah Pemerintah Kota Semarang dalam upaya mendongkrak pariwisata di Kecamatan Gunungpati adalah sebagai berikut. Dinas Kebudayaan dan Pariwisata Kota Semarang optimis dengan program pembangunan 1000 homestay diberbagai destinasi wisata. Hal ini bertujuan untuk turut mengembangkan potensi wisata di Kota Semarang salah satunya Kecamatan Gunungpati. Pemkot akan bekerja sama dengan perbankan melalui kredit lunak untuk homestay, dengan uang muka ringandan bunga di ba wah tujuh persen. Selain itu, Pemkot Semarang juga mendorong homestay merujuk pada pasar digital agar mempermudah wisatawan dan memperluas jaringan pasar. Adanya online system ini maka seluruh masyarakat dapat mengakses homestay tersebut dimanapun dan kapanpun. Pemberdayaan pelaku industri wisata halal dilakukan oleh Pemkot Semarang dalam upaya meningkatkan kualitas sumber daya manusia yang ada. Rencananya Kota Semarang akan dijadikan sebagai tuan rumah Festival Kesenian Rakyat Internasional (International Folklore Festival). Festival akan diikuti 500 wisatawan mancanegara dan 100 wisatawan domestik pada Agustus 2019 di Desa Wisata Kandri Kecamatan Gunungpati. Selain itu, pemerintah juga turut serta membangun infrastruktur yang masif di kawasan Gunungpati dengan tujuan untuk mempermudah akses ke lokasi wisata.

\section{Kesimpulan}

Era revolusi industri 4.0 dapat memberikan peluang maupun tantangan bagi Indonesia. Semua kegiatan dan aktivitasnya sudah berbasis online atau digital. Seluruh pihak mulai dari pemerintah, swasta dan masyarakat harus dapat menangkap peluang tersebut. Salah satu bentuk upaya yang dilakukan pemerintah adalah pengembangan kawasan industri pariwisata halal di Kecamatan Gunungpati Kota Semarang melalui optimalisasi teknologi digital. Pariwisata halal telah menjadi life style dari masyarakat dunia tidak hanya kaum muslim saja. Tentunya, dengan adanya kawasan industri pariwisata halal, wisatawan tidak perlu lagi canggung atau khawatir

\footnotetext{
${ }^{25}$ Jaelani, Aan. 2017. Halal Tourism Industry in Indonesia: Potencial and Prospects. Munich Personal RePEc Archive (MPRA) Paper No. 76237

${ }^{26}$ Ibid
} 
karena seluruh proses, sistem dan wisatanya itu sendiri sudah dijamin sesuai standar kehalalannya. Kecamatan Gunungpati sendiri mempunyai beberapa obyek wisata yang unggul namun memiliki beberapa kendala. Pelayanan kepada wisatawan yang kurang maksimal, belum adanya online reservation dan kawasan wisata halal bahkan promosi yang belum begitu masif menyebabkan wisata Gunungpati belum terlalu berkembang secara optimal. Oleh karena itu, peran teknologi digital sangatlah penting dalam mengembangkan potensi wisata Gunungpati menjadi kawasan industri pariwisata halal.

\section{Saran}

Adapun saran yang penulis berikan adalah agar pemerintah, pihak swasta dan masyarakat bersinergi dalam mengembangkan kawasan industri pariwisata halal di Kecamatan Gunungpati Kota Semarang. Penelitian ini bertujuan untuk meningkatkan semangat dalam optimalisasi teknologi digital akan tetapi masih diperlukan pembaruan untuk menyempurnakan gagasan yang penulis sampaikan. Penulis berharap untuk penelitian selanjutnya lebih inovatif dan up to date mengingat kondisi disetiap tahunnya yang berbeda-beda, sehingga dapat menjawab permasalahan tentang kawasan industri pariwisata halal.

\section{DAFTAR PUSTAKA}

Doğan, M. 2011. Türkiye' deislamiturizmingelişimi: 2002-2009. In Political Economy, Crises and Development. In, Şiriner, I., Morady, F., Mika, J., Aydın, M., Koç, Ş. A., Kapucu, H. ĖDoğan, E. (eds.), 471- 487. İstanbul: IJOPEC Publication.

El-Gohary, H. 2016. Halal Tourism, is it Really Halal?. Tourism Management Perspective. 19: 124 130.

Gillani, SH, Ijaz F dan Khan MM. 2016. Role of Islamic Financial Institutions in Promotion of Pakistan Halal Food Industry. Islamic Banking and Finance Review. 3 (1): 29-49.

Henderson, JC. 2010. Sharia-compliant hotel. Tourism and Hospitality Research. 10 (3): 246-254.

Jaelani, Aan. 2017. Halal Tourism Industry in Indonesia: Potencial and Prospects. Munich Personal RePEc Archive (MPRA) Paper No. 76237

Sahida, W. 2011. The Implementation of Shari'ah Compliance Concept Hotel: De Palma Hotel Ampang, Malaysia. 2nd International Conferences Humanities Historical and Social Sciences. Singapore

Ant "Memanfaatkan Media Digital untuk Kemajuan Pariwisata", diakses dari https://www.wartaekonomi.co.id/read177260/memanfaatkan-media-digital-untukkemajuan-pariwisata.html pada tanggal 21 Mei 2019 pukul. 13.24.

Basari, MT "Setahun, Jumlah Pengguna Internet Indonesia Bertambah 17 Juta", diakses dari https://teknologi.bisnis.com/read/20190228/101/894799/setahun-jumlah-penggunainternet-indonesia-bertambah-17-juta pada tanggal 21 mei 2019 pukul 13.12 . 
Fatkurrohman. 2018. Konsep dan Ruang Lingkup Wisata Halal. https://wisatahalal.sv.ugm.ac.id/2018/08/23/konsep-dan-ruang-lingkup-wisata-halal/. Diakses pada tanggal 10 April 2019 pukul 12.00 .

$\mathrm{H}$, Yanuar "Prospek baik Wisata Halal Indonesia", diakses dari https://www.liputan6.com/lifestyle/read/3375370/prospek-baik-wisata-halal-indonesia pada tanggal 22 Mei 2019 pukul 02.24.

Hidayah, SN "Prospek WIsata Halal Indonesia di Kancah Global", diakses dari https://www.alinea.id/kolom/prospek-wisata-halal-indonesia-di-kancah-global-b1Xgf9jV6 pada tanggal 22 Mei 2019 pukul 05.12.

Insetyonoto "WISATA SEMARANG: Yuk AKhir Pekan ke Desa Ini" diakses dari https://semarang.solopos.com/read/20160408/515/708648/wisata-semarang-yuk-akhirpekan-ke-desa-wisata-ini pada tanggal 22 Mei 2019 pukul 06.15

Kementerian Perindustrian RI. 2016. Making Indonesia 4.0: Strategi RIMasuk Revolusi Industri Ke-4. http://www.kemenperin.go.id/artikel/18967/Making-Indonesia-4.0:-Strategi-RI-MasukiRevolusi-Industri-Ke-4. Diakses pada tanggal 08 April 2019 pukul 07.01.

Koran Sindo. 2018. Prospek Wisata Halal Indonesia. https://nasional.sindonews.com/read/1355812/16/prospek-wisata-halal-indonesia1542585387. Diakses pada tanggal 09 April 2019 pukul 07.09.

Rais, Novia Syahidah "Apasih Wisata Halal?", diakses dari https://www.kompasiana.com/noviasyahidah/588872073097731407c94ce7/apa-sih-wisatahalal?page=all pada tanggal 22 Mei 2019 pukul 14.56.

Rizkiniswara, Leski "Pentingnya Teknologi dalam Sektor Pariwisata" diakses dari https://aptika.kominfo.go.id/2019/04/pentingnya-teknologi-dalam-sektor-pariwisata/ pada tanggal 21 mei 209 pukul 15.42 .

Satriana, ED dan Hayyun DF. 2018. Wisata Halal: Perkembangan, Peluang dan Tantangan. Jurnal of Halal Product and Research. 1 (2): 32-43.

Semarang Metro "Potensi Wisata Gunungpati Menjanjikan", diakses dari https://www.suaramerdeka.com/smcetak/baca/148375/potensi-wisata-gunungpatimenjanjikan pada tanggal 22 Mei 2019 pukul 14.49.

Tofan, Muhammad dkk, "Strategi Pengembangan Obyek Desa Wisata Kandri Kecamatan Gunungpati Kota Semarang ”, Islamic Banking and Finance Review, Vol. 3 No. 1, 2016, Hlm. 29-49.

Tresya, Viranda. 2017. Revolusi Industri 4.0: Pengertian, Prinsip dan Tantangan Generasi Milenial. https://www.maxmanroe.com/revolusi-industri-4-0.html. Diakses pada tanggal 08 April 2019 pukul 06.00. 